\title{
Indoor Thermal Factors and Symptoms in Office Workers: Findings from the U.S. EPA BASE Study
}

\author{
M. J. Mendell, A. Mirer \\ Environmental Energy Technologies Division \\ Indoor Environment Department \\ Lawrence Berkeley National Laboratory \\ Berkeley, CA
}

December 2008

This work was supported by grant 5 RO1 OH008117-02 from the Centers for Disease Control and Prevention (CDC)/National Institute for Occupational Safety and Health (NIOSH) and the U.S. Department of Energy under Contract No. DE-AC02-05CH11231. 
(in press, Indoor Air - accepted 11 December 2008)

\title{
Indoor Thermal Factors and Symptoms in Office Workers: Findings from the U.S. EPA BASE Study \\ M. J. Mendell, A. Mirer
}

\begin{abstract}
Some prior research in office buildings has associated higher indoor temperatures even within the recommended thermal comfort range with increased worker symptoms. We reexamined this relationship in data from 95 office buildings in the U.S. Environmental Protection Agency's Building Assessment Survey and Evaluation (BASE) Study. We investigated relationships between building-related symptoms and thermal metrics constructed from real-time measurements. We estimated odds ratios (ORs) and 95\% confidence intervals in adjusted logistic regression models with general estimating equations, overall and by season. Winter indoor temperatures spanned the recommended winter comfort range; summer temperatures were mostly colder than the recommended summer range. Increasing indoor temperatures, overall, were associated with increases in few symptoms. Higher winter indoor temperatures, however, were associated with increases in all symptoms analyzed. Higher summer temperatures, above $23^{\circ} \mathrm{C}$, were associated with decreases in most symptoms. Humidity ratio, a metric of absolute humidity, showed few clear associations. Thus, increased symptoms with higher temperatures within the thermal comfort range were found only in winter. In summer, buildings were overcooled, and only the higher observed temperatures were within the comfort range; these were associated with decreased symptoms. Confirmation of these findings would suggest that thermal management guidelines consider health effects as well as comfort.

Practical Implications: In winter, higher temperatures within the thermal comfort range are common in U.S. office buildings and may be associated with increased symptoms. In summer, temperatures below the thermal comfort range are common and may be associated with increased symptoms. Results from this large study thus suggest that in U.S. office buildings, less winter heating (in buildings that are in heating mode) and less summer cooling may reduce acute symptoms while providing substantial energy conservation benefits, with no expected thermal comfort penalty and, in summer, even thermal comfort benefits. If confirmed, this would be welcome news.
\end{abstract}

Key Words: indoor environmental quality, building-related symptoms, temperature, humidity, thermal factors 


\section{Background}

Thermal factors within buildings may play a substantial but unrecognized role in causing building-related symptoms. Some but not all prior research has found that warmer indoor temperatures even within the recommended thermal comfort range for office spaces are associated with higher prevalence of symptoms among office workers (Jaakkola, 1989; Skov, 1990; Wyon, 1992; Menzies, 1993; Mølhave, 1993; Reinikainen, 2001; Mendell, 2002; Reinikainen, 2003). For instance, Mendell (2002) found that increased temperatures even within a range below $25.6^{\circ} \mathrm{C}$ were associated with substantially increased severity of many symptoms, whereas Mølhave (1993) reported no significant association with sensory irritation symptoms of temperatures between 18 and $26^{\circ} \mathrm{C}$.

We have reexamined this question using data from the largest cross-sectional study to date on indoor environmental quality (IEQ) and occupant responses in a representative sample of U.S. office buildings. We used a variety of thermal metrics and performed both overall and seasonspecific analyses.

\section{Methods}

The Building Assessment Survey and Evaluation (BASE) Study was conducted by the U.S. Environmental Protection Agency (EPA) from 1994-1998. Descriptions of the study have been published previously (Brightman, 2000, U.S. Environmental Protection Agency, 2003). In brief, the study first selected a representative sample of 100 office buildings. Within each building, a single study space was randomly selected with, if possible, at least 50 occupants and served by no more than two ventilation air-handling units. (In this paper, the terms "building" and "study space" are considered equivalent.) All buildings were studied during one week, in either winter or summer. Standardized data on study buildings were collected from direct environmental measurements, inspections, and interviews with facility managers. Data on occupants were collected with self-completed questionnaires given to all occupants of each study space, on Thursday and Friday during the data collection week.

\section{Outcomes}

Analyses reported here investigated the associations of thermal factors with "building-related symptoms" (BRS), defined as symptoms experienced in the building at least one day per week during the last four weeks, and also improving when away from the building. Symptoms assessed in single questions in the questionnaire are referred to here as "specific" symptoms, even though some single questions asked about more than one symptom: stuffy or runny nose; sore or dry throat; dry, itching, or irritated eyes; and dry, itching, or irritated skin. Some specific building-related symptoms were grouped for analyses, with a positive response for a BRS "group" requiring positive response on at least one specific BRS in the group. Analyses reported here included seven (specific or grouped) BRS outcomes: lower respiratory (at least one of wheeze, shortness of breath, or chest tightness); cough; upper respiratory (at least one of stuffy or runny nose, sneezing, or sore or dry throat); dry, itching, or irritated eyes; fatigue or difficulty concentrating; headache; and dry, itching, or irritated skin. 


\section{Thermal Factors}

Temperature (dry bulb) and relative humidity $(\mathrm{RH})$ were measured at three fixed locations within each study space and also outside each building. Temperatures and relative humidities were measured continuously from Tuesday afternoon through Thursday afternoon of the study week at each building. Thermal data were recorded at five-minute intervals (with a few exceptions). Temperatures were recorded indoors at four different heights above the floor $(0.1,0.6,1.1$, and $1.7 \mathrm{~m})$, and relative humidities at one height $(1.1 \mathrm{~m})$. For this analysis, data from nine hours (8:00 am to 5:00 pm) on Thursday of the study week were used, when available. (For one building with incomplete data, thermal records from Tuesday were used.)

Analyses used several continuous and categorical metrics constructed from the original temperature and humidity monitoring data. First, for each building a mean value of temperature was calculated as a time-weighted average of measures recorded, at heights of $1.1 \mathrm{~m}$ and $1.7 \mathrm{~m}$, at three internal measurement sites, over the nine-hour workday. Mean temperature was a continuous variable with one value per building.

A set of "thermal stress" metrics for temperature was also constructed, based on the hypothetical idea that the cumulative time-weighted "exposure" above some critical temperature may be a better predictor of adverse effects of temperature than a simple mean. Each thermal stress metric estimated the time-integrated magnitude of temperature exposure above a specific hypothetical thermal "threshold." These continuous metrics were calculated for thresholds of 20, 21, 22, and $23^{\circ} \mathrm{C}$. The metrics (using the averaged measures recorded at each point in time at $1.1 \mathrm{~m}$ and 1.7 $\mathrm{m}$ above the floor at three internal measurement sites) were calculated as the product of the number of degrees above the selected temperature threshold for each measurement time interval and the number of hours above that threshold, for one workday. For example, a building with a constant temperature of $24^{\circ} \mathrm{C}$ over a nine-hour workday would accumulate 27 "degree-hours above $21^{\circ} \mathrm{C} "$ and 18 degree-hours above $22^{\circ} \mathrm{C}$.

From each of the continuous temperature metrics described above (mean temperature and the thermal stress metrics), alternate categorical forms of the variables were also created. From the continuous mean temperature variable, we constructed a four-category variable based on quartiles (i.e., with approximately equal numbers of observations in each category). From each of the continuous thermal stress variables, we constructed a three-category variable, with category boundaries set at the number of degree-hours above each temperature threshold that would be expected in a building with a constant temperature of $23^{\circ} \mathrm{C}$, and of $24^{\circ} \mathrm{C}$.

For each building, a mean value of RH was calculated as the time-weighted average of measures recorded, at a height of $1.1 \mathrm{~m}$ at three internal measurement sites, over the nine-hour workday. Mean RH was a continuous variable. We also created an alternate categorical form of the variable, with four categories based on quartiles. We calculated an additional "absolute" (i.e., non-relative) metric of humidity - the "humidity ratio," representing the mass of water vapor divided by the mass of dry air. This metric, unlike RH, is not functionally dependent on temperature (i.e., does not vary as temperature changes even if the amount of water in the air is constant). The humidity ratio $(W)$ was calculated using the averaged $\mathrm{RH}$ and temperature data via the following formula (full derivation is provided in an online Appendix) (ASHRAE, 2005a): 


$$
W=0.62198 \cdot \frac{p_{w}}{p-p_{w}}
$$

where $\mathrm{p}=$ atmospheric pressure (assumed here to be at sea level) and $\mathrm{p}_{\mathrm{w}}=$ partial pressure of water vapor at a specific temperature and relative humidity. The humidity ratio, like RH, was a continuous variable. From this continuous variable for humidity ratio, we also created an alternate categorical form of the variable, with three categories.

Finally, we estimated values for a continuous mean enthalpy variable (in $\mathrm{kJ} / \mathrm{kg}$ ) that combined information on both humidity ratio and temperature in one metric (Fang, 1998).

Thus, the metrics representing thermal factors in the analyses included 15 variables: a continuous and a categorical variable for mean temperature; continuous and categorical variables for thermal stress over $20,21,22$, and $23^{\circ} \mathrm{C}$; continuous and categorical variables for both mean relative humidity and mean humidity ratio; and a continuous variable for mean enthalpy. Models generally included, as thermal metrics, either one temperature variable (either continuous or categorical) plus one humidity variable (continuous or categorical), or the enthalpy variable alone.

\section{Confounding Variables}

We considered a number of environmental and personal factors as potential confounders. Potential environmental confounding variables were: outdoor air ventilation rate (estimated from measured volumetric flow (Mendell, 2005)), season of study, age of building, cooling degree days, and heating degree days. (Cooling and heating degree days are included as indicators of local climatic conditions, with values at a specific location equal to the cumulative number of degrees in a year by which the daily mean temperature, for cooling degree days, is above $18.3^{\circ} \mathrm{C}$, and for heating degree days, is below $18.3^{\circ} \mathrm{C}$.) Personal variables considered to be potential confounders were gender, age, education, smoking status, asthma, mold allergy, hay fever, type of workstation, comfort of chair, satisfaction with work station, job satisfaction, job demand, job conflict, and years worked in building.

\section{Analysis Methods}

All analyses were conducted in SAS V9.1 (SAS, Cary, NC). Categorical variables for thermal risk factors were examined in univariate analyses. Those with insufficient variation were recategorized or excluded. In bivariate logistic regression models (SAS PROC LOGISTIC), we estimated unadjusted ORs for each symptom outcome and both categorical and continuous forms of the thermal variables. As appropriate, categories were combined, and continuous variables rescaled. For each symptom outcome, we also constructed "thermal-factor adjusted" logistic models, each including two independent variables: a continuous temperature metric plus a continuous humidity ratio metric. These models were each constructed with the overall data, and then separately for the winter and summer data.

Finally, for each symptom outcome, we estimated associations with thermal risk factors in multivariate logistic regression models adjusting for confounding factors (SAS PROC 
LOGISTIC). Confounders forced into models included gender, season, smoking, asthma, cooling degree-days and heating degree-days. For each symptom model, other confounders were included if they changed estimates for temperature or humidity by at least $15 \%$. If any model was found to have inadequate fit (Hosmer-Lemeshow goodness-of-fit $p$-value $<0.05$ ), the least confounding variables were removed sequentially until fit was satisfactory. We performed multiple imputation of missing values for personal variables (SAS PROC MI and PROC MIANALYZE). (Multiple imputation is a standard method for reducing bias in analyses that would be caused by exclusion of all observations with any missing variable values. Multiple imputation, based on probability distributions estimated from available data, generates a number of likely values for each missing value, retains the observations with the imputed values, constructs multiple parallel analysis models which incorporate the different imputed values, and then combines the estimates produced by the multiple models). After construction of the final logistic regression models, we recreated logistic regression models with the same variables but using generalized estimating equations (GEE) with exchangeable correlation matrix to adjust for potential correlation of subjects within buildings (SAS PROC GENMOD) (Zeger, 1986). Estimates from final GEE regression models are reported here in tables and text as odds ratios (ORs) and 95\% confidence intervals (CIs).

Also, to test whether the relationship of thermal factors to symptoms differed between summer and winter, we constructed multivariate models stratified by season of study. Statistical tests of effect modification were performed for season and continuous temperature in multivariate models with temperature*season terms.

\section{Results}

Of 100 BASE buildings, 95 were included in analyses. Three naturally ventilated study spaces were excluded, as effects of thermal factors are known to differ in these, compared to airconditioned buildings (Brager, 2000). Two additional buildings with unusually low mean temperatures $\left(19.5\right.$ and $20.1^{\circ} \mathrm{C}$ vs. $\left.21.6-24.8^{\circ} \mathrm{C}\right)$ were excluded. Initial analyses included 4,166 respondents.

\section{Descriptive Analysis}

Table 1 provides descriptive data on thermal variables in the 95 included buildings. For mean building temperature, the median was $23.2^{\circ} \mathrm{C}$ and the range $21.6-24.8^{\circ} \mathrm{C}$. Temperature ranges observed in summer and winter were similar, but with median and maximum indoor temperatures 0.5 degrees cooler in summer than in winter (Figure 1). Therefore, because the recommended comfort range for summer is several degrees warmer than that for winter, observed summer temperatures were predominantly below the recommended thermal comfort range, while observed winter temperatures more evenly spanned the recommended range. For relative humidity, the median was $39.1 \%$ and the range $9.4-62.4 \%$, with substantially lower values in winter relative to summer. Humidity ratios were also substantially lower in winter than in summer.

\{Figure 1 about here\} 
The study population has been described elsewhere (Brightman, 2000). In summary, 66\% of subjects were female, 55\% were at least 40 years old, 15\% were current smokers, and 17\% held managerial jobs. Highest education level was at least a college degree for 53\%. Overall prevalences of the seven BRS outcomes (see bottom of Table 2) ranged from $4.2 \%$ for lower respiratory symptoms to $20.8 \%$ for upper respiratory symptoms.

All 95 buildings had data available for all initial continuous thermal variables. The left columns in Table 2 show the thermal variable categories and their sizes. Categorical variables for degreehours over 20,21 , and $22^{\circ} \mathrm{C}$ had insufficient numbers in the lower categories, and were not included in analyses; however, the continuous forms of these variables were included.

\section{Unadjusted Analyses:}

Table 2 shows bivariate (unadjusted) associations of outcomes with the categorical thermal factor variables. The categorical variable for mean temperature quartiles showed a monotonic increase for cough and a small and uneven increase for eye symptoms, but no clear pattern of increase for other outcomes. The 3-category temperature variable for degree-hours above $23^{\circ} \mathrm{C}$ showed monotonic increases of different magnitudes for all outcomes, except headache and skin.

The categorical variable for relative humidity showed no evident relationships with symptom outcomes, although the highest level was associated with possible small reductions in all symptoms except eye symptoms. Higher values of the categorical variable for humidity ratio (multiplied by $10^{3}$ ) were associated with a small monotonic decrease in upper respiratory symptoms and fatigue/difficulty concentrating, along with a small but uneven decrease in headache, but no other evident associations. The enthalpy variable showed little evident pattern of association with symptoms, except for a tendency to an inverse relationship with upper respiratory and skin symptoms.

Table 3 shows the bivariate associations of outcomes with the continuous forms of the mean temperature variable, and also of the degree-hour temperature variables, which were scaled (divided by 9) so that each unit increase covered a similar proportion of the range as with the mean temperature variable. ORs shown are for unit increases of each variable within the observed range, described in footnote 2 of the Table. For the mean temperature and all four degree-hour variables, all estimates exceeded 1.0, showing a positive association between higher temperature exposure and all symptoms assessed. For each symptom, magnitude of the ORs were generally very similar across all these continuous temperature variables, but ORs showed the largest elevations for cough, eye symptoms, and upper respiratory symptoms.

Among the continuous variables for relative humidity and for humidity ratio $\left(\mathrm{x} 10^{3}\right.$, scaled to make unit increases cover approximately the same proportion of the range as with relative humidity), little unadjusted association with symptoms was apparent, except for a tendency toward a small negative association between these humidity variables and both skin and upper respiratory symptoms. The continuous enthalpy variable showed no evident association with any symptom.

Thermal-factor adjusted analyses - overall and by season 
ORs for temperature variables and humidity ratio variables, when adjusted for each other, showed little change from crude ORs (not shown). Estimated ORs and CIs for the continuous mean temperature variable and the four degree-hours temperature metrics, adjusted for humidity ratio, are shown at the top of Figure 2 (labeled "All"). As with the crude estimates, some of the metrics showed association with increased cough, eye symptoms, and possibly upper respiratory symptoms. Associations for the mean metric and the degree-hour metrics were similar, except that degree-hours above $23^{\circ} \mathrm{C}$ generally were less strongly associated with outcomes.

\section{\{Figure 2 about here\}}

Figure 2 also shows the thermal factor-adjusted estimates for the same five continuous temperature metrics and the symptom outcomes in season-specific analyses. For winter data, higher temperature by all metrics were associated with some increase in all symptoms. Five of seven symptoms showed a slight increase across the thermal metrics, with a large increase for degree-hours above $23^{\circ} \mathrm{C}$. For the summer data, in contrast, while temperature/symptom associations were mixed, six of seven symptoms showed gradually decreasing ORs across the thermal metrics, with the largest decreases for degree-hours above $23^{\circ} \mathrm{C}$ (ORs from 0.58 to 0.84 )

Multivariate-adjusted analyses - overall and by season

Table 4 provides estimated ORs and 95\% CIs from three groups of multivariate logistic regression models with GEE for associations between thermal factor metrics and building-related symptoms.

Model Group I contained categorical variables for quartiles of mean temperature and 3 categories of humidity ratio. For Model Group I, increasing temperature showed some limited evidence of relationships with increased odds of eye symptoms and cough, and less consistent associations with increased headache and decreased skin symptoms. Relationships of humidity ratio with symptoms were most clearly apparent in a positive association with cough and less clearly in positive associations with eye symptoms and negative associations with lower and upper respiratory symptoms.

Model Group II contained continuous variables for mean temperature (ORs are per ${ }^{\circ} \mathrm{C}$ ) and humidity ratio (ORs are per unit of humidity ratio $\mathrm{x} 10^{3}$ ). In the Group II overall (All) models, increasing (continuous) temperature was related most strongly to increased eye symptoms and cough. Associations in winter between increasing mean temperature and symptoms were more strongly and consistently positive, with elevations in ORs for all seven symptoms, ranging from 1.17 to 1.68 per $1{ }^{\circ} \mathrm{C}$. For the $3.2^{\circ} \mathrm{C}$ temperature increase from the lowest to the highest winter temperatures observed, estimated ORs for cough, eye symptoms, and fatigue/difficulty concentrating were 5.26, 3.00, and 3.28 respectively. In the summer data, the only strong relationship was a negative association, $\mathrm{OR}=0.80$ per $1^{\circ} \mathrm{C}$, with fatigue/difficulty concentrating. For the $2.8^{\circ} \mathrm{C}$ temperature increase from the lowest to the highest summer temperatures observed, the estimated OR for fatigue/difficulty concentrating was 0.54 . P-values $\leq 0.20$ for effect modification of continuous temperature by season were found for cough, eye symptoms, fatigue/difficulty concentrating, headache, and skin symptoms. 
Relationships of humidity ratio to symptoms were not evident in the overall analyses in Model II, except for some positive association with cough. There was some tendency toward a negative association in winter with all symptoms, most apparent in lower and upper respiratory symptoms, but associations in summer were weak and mixed, with a tendency toward increased cough, upper respiratory symptoms, and eye symptoms, but toward decreased fatigue/difficulty concentrating.

Model Group III contained continuous variables for degree-hours above $23^{\circ} \mathrm{C}$ and humidity ratio. In the Group III overall (All) models, increasing thermal exposures above $23^{\circ} \mathrm{C}$ had similar associations with symptoms as seen with increasing mean temperature (Model II). In winter, thermal exposures above $23^{\circ} \mathrm{C}$ were associated with similar but generally somewhat larger increases in most symptoms compared to mean temperature. In summer, however, increasing exposure to temperatures above $23^{\circ} \mathrm{C}$ was associated with decrease in six of seven symptoms, with ORs ranging from 0.58 to 0.84 . These were stronger and more consistent decreases in symptoms than those seen for mean temperature. Relationships of humidity ratio to symptoms in Model III were similar to those in Model II.

\section{Discussion}

\section{Synthesis and interpretation of results}

Comparison of season-specific to overall analyses here suggest that associations of BRS with both temperature and humidity ratio need to be looked at separately in winter and summer. While for the year overall, temperature had clear associations only with a few symptoms, in the winter data, increasing mean temperatures from 21.6 to $24.8^{\circ} \mathrm{C}$, and also greater cumulative thermal exposures above $23^{\circ} \mathrm{C}$, were associated with substantial increases in most symptoms. In summer, in contrast, while increasing mean temperatures from 21.6 to $24.8^{\circ} \mathrm{C}$ were associated with decrease in only fatigue/difficulty concentrating, increased thermal exposures over $23{ }^{\circ} \mathrm{C}$ were associated with decreases in most symptoms. The summer exposures above $23^{\circ} \mathrm{C}$ were equivalent to temperatures within the bottom half of the summer thermal comfort range. No data were available to compare temperatures in the lower and upper halves of the summer comfort range to see if symptoms increase again at the higher temperatures, as in winter.

Any adverse effects of heat would be expected to occur in summer at higher temperatures than in winter, as people may acclimate to and dress for slightly warmer summer temperatures. For instance, as shown in Figure 1, at the 47\% observed median summer building-mean RH in the BASE study, the ASHRAE summer comfort range is about $23.2-26.3^{\circ} \mathrm{C}$, whereas in winter, at the $27 \%$ observed median winter building-mean RH in the BASE study, it is substantially lower, between about $22.4-24.5^{\circ} \mathrm{C}$ (ASHRAE, 2005b). Thus, if there is a threshold temperature above which mild thermal stress causes increased symptoms (through still unknown mechanisms), this threshold may plausibly be several degrees higher in summer. However, average temperatures in the BASE buildings were almost $0.5^{\circ} \mathrm{C}$ cooler in the summer than in the winter (Table 1 ).

The findings here are consistent with occurrence of thermal stress in winter (seen as an increase in all symptoms) even at the warmer temperatures within the recommended winter range. The thermal stress variable, for cumulative exposure time above $23^{\circ} \mathrm{C}$, showed similar or somewhat 
stronger associations with increased symptoms than did mean temperature. This may provide initial evidence that, for some symptoms, a thermal stress metric better describes the physiologic basis behind the symptoms reported; however, differences seen were small. In contrast, the observed summer temperatures ranged from $1.5^{\circ} \mathrm{C}$ below the summer comfort range up to just below the middle of the recommended range, lacking temperatures at the higher end of the recommended summer comfort range. In this observed summer range, there were apparent effects from sub-optimal temperatures - the increase in most symptoms associated with temperatures below the thermal comfort range. The substantially stronger associations seen between some symptoms and the thermal stress variable than with the mean temperature variable may indicate that cumulative exposure to low temperatures is a better way to describe and study this phenomenon; alternatively, there may be a threshold effect. Also, though not analyzed here, the generally low summer temperatures in BASE buildings are likely to be associated with substantial thermal discomfort.

We found no clear evidence that, within the observed temperature range, risk of symptoms in winter increased only above some threshold temperature, although higher cumulative thermal exposures above $23^{\circ} \mathrm{C}$ were associated with somewhat larger increases in symptoms than higher mean temperature. Because limited data were available here for assessing lower temperature thresholds in winter or higher thresholds in summer, other datasets with more variation may be required to answer this question. It is not clear through what mechanisms slightly increased temperatures within a comfortable range in winter would increase a wide variety of symptoms. Nor is it clear how temperatures below the comfortable range in summer would increase many symptoms.

Humidity, modeled as humidity ratio because this is not functionally dependent on temperature, had only minor and somewhat inconsistent season-specific adjusted associations with symptoms. The strongest associations seen in the models including mean temperature were, in winter, a $16 \%$ reduced odds of lower respiratory symptoms per $10^{-3}$ units of humidity ratio, and in summer, a $12 \%$ increased odds of cough per $10^{-3}$ units of humidity ratio. Enthalpy, a single-variable summary of temperature and humidity, did not seem to provide a useful summary of their associations with symptoms.

Findings in this analysis also have potential implications for energy use in conditioning of buildings. Maintaining office buildings at warmer temperatures in summer than those observed, with the goal of reducing symptoms, would also result in substantial savings in energy use and financial costs from avoided air-conditioning. Maintaining office buildings at cooler temperatures in winter, within the lower range of the comfort zone, with the goal of reducing symptoms, does not have a symmetric, direct link to reduced energy use and financial costs. For many of the BASE buildings studied in winter, outdoor temperatures were moderate - most above $10^{\circ} \mathrm{C}$ and many above $15^{\circ} \mathrm{C}$ - based on recorded outdoor air temperatures (personal communication, Greg Brunner, U.S. EPA). These moderate temperatures, in combination with the large amounts of heat generated within buildings by occupants, lights, and equipment, indicate that many of the BASE winter buildings may have been in cooling rather than heating mode, especially in the core of the buildings away from walls and windows. It is typical for many buildings in winter, especially large ones, to use air-conditioning or, for those buildings with economizer cycles and sufficiently cool outdoor air, to bring in cool outdoor air for "free 
cooling." Thus, if maintaining U.S. buildings at cooler indoor temperatures in winter would reduce occupant symptoms, this would result in energy and cost savings only for the buildings in heating mode. Lowering temperatures in winter within buildings in cooling mode, however, would have either little cost or energy implications (for buildings cooling with cool outside air) or could actually involve increased cost and energy (for buildings requiring increased airconditioning).

\section{Comparison to prior findings}

Prior studies have had inconsistent findings on whether increasing indoor temperatures within the recommended comfort range are associated with increased symptoms in office workers. The following studies are listed in order of most positive to most negative findings on this question. Mendell (2002) found that increased temperatures within a range of $22.2-25.6^{\circ} \mathrm{C}$, with overall mean $23.7^{\circ} \mathrm{C}$ (all in summer), were associated in adjusted models with increased severity of every symptom investigated. Menzies (1993), in an unadjusted cross-sectional analysis of data collected half in the spring and half in the fall, reported that office workers were increasingly likely to report any symptom as indoor temperatures increased from 21 to $25^{\circ} \mathrm{C}$, with crude prevalence increasing from about $40 \%$ to $60 \%$. Wyon (1992) reported that in a controlled intervention study, reduction of workspace temperatures by $1.5^{\circ} \mathrm{C}$ significantly reduced intensity of symptoms in occupants, but did not report specific temperature levels, symptoms reduced, season of study, or any numeric results. Jaakkola (1989) reported from adjusted analyses of cross-sectional data collected in winter and spring from an office building that mean sick building symptom score at work increased with a significant linear trend as temperatures rose from below $22^{\circ} \mathrm{C}$ to above $24^{\circ} \mathrm{C}$; however, these scores reflected symptoms experienced either equally at home and work, or mostly at work. Skov (1990) reported from a cross-sectional study of office buildings that temperatures between $23-24^{\circ} \mathrm{C}$ measured in winter and spring were associated with higher prevalence of frequent, work-related general symptoms (headache, fatigue, or malaise) than either higher or lower temperatures $\left(21-23\right.$ and $\left.>24^{\circ} \mathrm{C}\right)$, but only in one of four analysis models constructed; temperatures were not associated with mucosal symptoms in any analysis model. Reinikainen (2001) reported, from a field intervention on humidification in winter, that increasing indoor temperatures above $22^{\circ} \mathrm{C}$ were associated with increased intensity of sick building symptoms in non-humidified conditions only, and with increased dryness symptoms in both humidified and non-humidified conditions. Reinikainen (2001) reported that increasing temperatures between 18 and $26^{\circ} \mathrm{C}$ in winter, but only in non-humidified conditions, were associated with increased pharyngeal dryness; other symptoms were not associated with temperature. Mølhave (1993) found no significant effects of temperatures between 18 and $26^{\circ} \mathrm{C}$ on sensory irritation symptoms in a controlled experimental study.

Seasonal modification of associations between temperature and symptoms has apparently not been examined in prior office studies. Comparable winter-specific findings do not seem to be available, although the winter-specific findings in analyses here are generally consistent with the prior findings of Jaakkola (1989) in winter and spring. The summer-specific findings here can only be compared to those of Mendell (2002). A strong positive associations of symptoms with increasing indoor summer temperatures, not seen in this study, may have been seen by Mendell et al. (2002) because of the higher range of observed temperatures spanning more of the thermal comfort range ( $80 \%$ vs. $40 \%$ ), suggesting that both very low summer temperatures (as observed in BASE) and higher summer temperatures even in mid to high levels within the comfort zone 
are associated with greater symptoms. Alternatively, findings in the prior study (Mendell, 2002) which evaluated current symptom severity on the same day as temperature measurements and used a stronger repeated measures prospective design, may more accurately depict temperature/symptom relationships in summer. More detailed data collected on symptoms across a full range of summer temperatures will be needed to resolve this question.

Reinikainen and Jaakkola (2003) found that increasing relative humidity reduced pharyngeal symptoms, and Mendell et al. (2002), found increasing humidity ratio (in summer) to be associated with decreased throat, chest, and fatigue symptoms. These limited prior findings are consistent with the negative association found here in winter between increasing moderate levels of humidity and upper and lower respiratory symptoms and fatigue, but only somewhat consistent with summer findings.

\section{Limitations of analysis}

There are a number of factors in this analysis that may have tended to bias the results, by either exaggerating or diminishing associations seen compared to the true levels of association. For instance, the BASE study, although providing the largest available data set on occupant responses to indoor environments in representative U.S. office buildings, has multiple limitations. The study is subject to the many limitations of cross-sectional designs. Recall of subjective symptoms is subject to many potential biases, which may either exaggerate or diminish true associations. Although the BASE data set contains over 4000 individual subjects, environmental parameters are measured in only 100 buildings. The limited observed variation in indoor temperature limits the ability to identify true relationships.

Thermal parameters measured on the same day as reporting of subjective symptoms during the last four weeks may not well approximate thermal conditions during the relevant prior four weeks. Because the thermostat settings ("set points") that control temperatures in commercial buildings are infrequently changed, the one-day mean temperatures used in these analyses are likely to be reasonable estimates of temperatures in study spaces during the prior four weeks of symptom recall. (This is less true during "swing seasons" of spring and fall, because the differing heating and cooling set points for winter and summer may alternate then, but BASE buildings were studied in either winter or summer.) To the extent that temperatures used in analyses did not represent temperatures during the period of symptom recall, the resulting "nondifferential misclassification" is likely to obscure true associations. Relationships seen here between continuous thermal metrics and symptoms should not be generalized from these findings outside of the ranges observed in the BASE buildings.

The formula used to estimate humidity ratio assumed all buildings were at sea level because each building was identified only by state. Some buildings may have been substantially above sea level, leading to underestimates in humidity ratio of $20 \%$ or more, or in enthalpy of $10 \%$ or more (personal communication, Greg Brunner, U.S. EPA). These kinds of errors are likely to have reduced ability to see any true relationships between both these thermal metrics and symptoms.

Validity of estimates from logistic regression models rest on several primary assumptions, the most important of which is that the independent variables in the model have linear relationships with the logit $(\log$ OR) of the symptom outcome variables. While the basic logistic model also 
assumes an independence between observations (building occupants) that may not be valid within buildings, the logistic regression models with GEE used here adjust for correlations among occupants within each building. A full discussion of the use and limitations of logistic regression models is available in Hosmer and Lemeshow (2000).

While the models used here assume that log ORs for thermal metrics have linear relationships with symptom outcomes, we have not established that this is correct. However, the continuous forms of the thermal metric variables were preferred because the categorical forms exhibited large and erratic variability in estimates depending on category boundaries and on the specific other covariates in the models (not shown). Estimates also varied somewhat in analyses using thermal data from the Thursday workday (on which most of the questionnaires were completed), or the Tuesday through Thursday workdays, with the latter showing somewhat less strong associations with symptom outcomes in summer (not shown).

Because this analysis assessed associations between many thermal metrics and seven outcomes, some of the associations found may have occurred by chance in these data despite lack of true associations. While this phenomenon does not upwardly bias the size of associations, the pvalues and 95\% confidence intervals presented may exaggerate the evidence against random association. However, patterns of association with multiple symptoms, such as seen here for higher winter temperatures and lower summer temperatures, are less likely to be chance findings, whether or not "statistically significant."

\section{Conclusions}

One clear descriptive finding from these BASE data is that U.S. office buildings seem to be kept at similar temperatures throughout the year, and even somewhat cooler temperatures in summer, despite a warmer recommended range for thermal comfort in summer. Analytic findings here suggest:

1) a broad range of acute symptom effects in occupants at the warmer end of the recommended winter thermal comfort range, even with temperatures above $23^{\circ} \mathrm{C}$, which is below the midpoint of the comfort range. Thus, maintaining buildings in winter at the cooler end of the recommended comfort range may substantially reduce many acute symptoms, without reducing thermal comfort, and also save energy in buildings that are in heating mode.

2) a broad range of acute symptom effects in occupants within the substantial number of overcooled office buildings in summer. Reducing summer cooling to allow temperatures to stay within the thermal comfort guidelines may thus benefit occupant symptoms, and would certainly benefit occupant thermal comfort while also saving energy.

3) less clear associations between symptoms and humidity ratio, but suggesting small reduction in one or more symptoms with higher moderate humidities in winter. (Note, however, that prior analyses of the BASE data showed increased symptoms associated with the presence of badly maintained humidification systems, which included $40 \%$ of the humidification systems studied (Mendell, 2008).)

In winter, temperatures lower than $23^{\circ} \mathrm{C}$ were associated with substantial reductions in most symptoms, whereas in summer, temperatures greater than $23^{\circ} \mathrm{C}$ were associated with substantial reductions in symptoms. In summer, and in winter in buildings in heating mode, this suggests 
benefits from less thermal conditioning of the indoor air than was observed. It is often assumed that energy conservation measures in buildings will decrease thermal comfort. Findings here suggest, in contrast, opportunities for substantial energy savings in many offices, accompanied by health benefits, with no comfort penalty or even with comfort benefits. Energy-saving changes in current thermal management practices in U.S. buildings (less heating in winter, less cooling in summer) may have both health and thermal comfort benefits.

Additional research to confirm these findings is needed to support indoor thermal guidelines that formally consider acute health effects in addition to comfort. We recommend new assessments of the season-specific associations between thermal factors and same-day occupant symptoms across a broader range of temperatures. It is important to have data documenting relationships between thermal factors, comfort, and health across the seasons, to properly determine optimal and acceptable indoor temperatures year-round. 


\section{Appendix 1. Formula for humidity ratio used in analyses of the BASE data}

We calculated the humidity ratio in order to obtain a humidity metric that, unlike relative humidity, was not highly correlated with temperature. Using the averaged RH and temperature, the humidity ratio $(W)$ was calculated via the following formulas (ASHRAE, 2005a):

$$
W=0.62198 \quad \frac{p_{W}}{p-p_{w}} \quad \text { (Eq. 1), }
$$

the saturation pressure over liquid water,

$$
\ln \left(p_{\text {ws }}\right)=\frac{\mathrm{C}_{8}}{\mathrm{~T}}+C_{9}+C_{10} T+C_{11} T^{2}+C_{12} T^{3}+C_{13} \ln (T) \text { (Eq. 2), }
$$

and the relative humidity,

$$
\phi=\frac{p_{w}}{p_{w s}} \text { (Eq. 3). }
$$

By manipulating Eq. 2, the saturation pressure, $p_{\mathrm{ws}}$, can be found:

$$
\mathrm{p}_{\mathrm{ws}}=\mathrm{e}^{\frac{\mathrm{C}_{8}}{\mathrm{~T}}+C_{9}+C_{10} T+C_{11} T^{2}+C_{12} T^{3}+C_{13} \ln (T)} \text {. (Eq. 4) }
$$

Manipulating Eq. 3 gives the partial pressure of water vapor, $p_{w}$ :

$$
p_{w}=\phi \cdot p_{w s} \cdot 0.01 \text {. (Eq. 5). }
$$

$W$ is obtained by substituting Eq. 4 and Eq. 5 back into Eq. 1:

$$
W=0.62198 \cdot \frac{0.01 \cdot \phi \cdot \mathrm{e}^{\frac{\mathrm{C}_{8}}{\mathrm{~T}}+C_{9}+C_{10} T+C_{11} T^{2}+C_{12} T^{3}+C_{13} \ln (T)}}{p-0.01 \cdot \phi \cdot \mathrm{e}^{\frac{\mathrm{C}_{8}}{\mathrm{~T}}+C_{9}+C_{10} T+C_{11} T^{2}+C_{12} T^{3}+C_{13} \ln (T)}} \text { (Eq. 6). }
$$

where $\phi$ is relative humidity, $\mathrm{T}$ is absolute temperature in degrees Kelvin, and $p=$ $101.325 \mathrm{kPa}$ (barometric pressure of $1 \mathrm{~atm}$ in kilopascals, assuming altitude $=0$ ).

Constants:

$\mathrm{C}_{8}=-5.8002206 \mathrm{E}+03$

$\mathrm{C}_{9}=1.3914993$

$\mathrm{C}_{10}=-4.8640239 \mathrm{E}-02$

$\mathrm{C}_{11}=4.1764768 \mathrm{E}-05$

$\mathrm{C}_{12}=-1.4452093 \mathrm{E}-08$

$\mathrm{C}_{13}=6.5459673$ 


\section{Acknowledgements}

This work was supported by grant 5 RO1 OH008117-02 from the Centers for Disease Control and Prevention (CDC)/National Institute for Occupational Safety and Health (NIOSH). The BASE study was conducted and the data for these analyses were provided by the Indoor Environments Division, Office of Radiation and Indoor Air, Office of Air and Radiation of the U.S. Environmental Protection Agency (EPA). Its contents are solely the responsibility of the authors and do not necessarily represent the views of CDC/NIOSH or of the U.S. EPA. We thank William Fisk, David Lorenzetti, Hal Levin, and Greg Brunner for their helpful review of the draft manuscript, and Quanhong Gomez-Lei for initial work on the data analyses.

\section{References}

Ashrae (2005a) ASHRAE Handbook: Fundamentals, Atlanta, GA, American Society of Heating, Refrigerating and Air-Conditioning Engineers, Inc.

Ashrae (2005b) ASHRAE Standard 55-2004 -- Thermal Environmental Conditions for Human Occupancy, Atlanta, GA, American Society of Heating, Refrigerating and AirConditioning Engineers, Inc.

Brager, G.S. and De Dear, R. (2000) "A standard for natural ventilation", ASHRAE Journal, 42, 21-28.

Brightman, H.S. and Moss, N. (2000) Sick building syndrome studies and the compilation of normative and comparative values, In: Spengler, J., Samet, J. M. and Mccarthy, J. F. (eds) Indoor Air Quality Handbook, New York, McGraw-Hill, 3.1-3.32.

Fang, L., Clausen, G. and Fanger, P.O. (1998) "Impact of temperature and humidity on the perception of indoor air quality", Indoor Air, 8, 80-90.

Hosmer, D.W, and Lemeshow, S. (2000), Applied Logistic Regression ( $2^{\text {nd }}$ ed.). John Wiley and Sons, Inc., Hoboken, NJ.

Jaakkola, J.J. and Heinonen, O.P. (1989) "Sick building syndrome, sensation of dryness and thermal comfort in relation to room temperature in an office building: Need for individual control of temperature", Environment International, 15, 163-168.

Mendell, M.J., Fisk, W.J., Petersen, M.R., Hines, C.J., Dong, M., Faulkner, D., Deddens, J.A., Ruder, A.M., Sullivan, D. and Boeniger, M.F. (2002) "Indoor particles and symptoms among office workers: results from a double-blind cross-over study", Epidemiology, 13, 296-304.

Mendell, M.J., Lei, Q., Apte, M. and Fisk, W.J. (2005) "Estimated ventilation rates and workrelated symptoms in U.S. office buildings -- the BASE Study". In: Proceedings of Indoor Air 2005: Proceedings of the 10th International Conference on Indoor Air Quality and Climate, Vol. V, pp. 3758-3762.

Mendell, M.J., Lei-Gomez, Q., Mirer, A., Seppänen, O., Brunner, G. 2008) "Risk factors in heating, ventilating, and air-conditioning systems for occupant symptoms in U.S. office buildings: the U.S. EPA BASE study" Indoor Air, 18, 301-316.

Menzies, R., Tamblyn, R., Farant, J.P., Hanley, J. and Nunes, F. (1993) "The effect of varying levels of outdoor-air supply on the symptoms of sick building syndrome", $N$ Engl J Med, 328, 821-827.

Mølhave, L., Liu, Z., Jorgensen, A.H., Pedersen, O.F. and Kjaergaard, S.K. (1993) "Sensory and physiological effects on humans of combined exposures to air temperatures and volatile organic compounds", Indoor Air, 3, 155-169. 
Reinikainen, L.M. and Jaakkola, J.J. (2001) "Effects of temperature and humidification in the office environment", Arch Environ Health, 56, 365-368.

Reinikainen, L.M. and Jaakkola, J.J. (2003) "Significance of humidity and temperature on skin and upper airway symptoms", Indoor Air, 13, 344-352.

Skov, P., Valbjorn, O., Pedersen, B.V. and Group, T.D.I.C.S. (1990) "Influence of indoor climate on the sick building syndrome in an office environment." Scand J Work Environ Health, 16, 363-371.

U.S. Environmental Protection Agency (2003) A standardized EPA protocol for characterizing indoor air quality in large office buildings, Washington, D.C., U.S. Environmental Protection Agency.

Wyon, D.P. (1992) "Sick Buildings and the Experimental Approach", Environmental Technology, 13, 313-322.

Zeger, S.L. and Liang, K.Y. (1986) "Longitudinal Data Analysis for Discrete and Continuous Outcomes", Biometrics, 42, 121-130. 
Table 1. Descriptive summary of thermal metrics used in analyses of 95 U.S. office buildings in the BASE data, collected 1994-1998

\begin{tabular}{lccc}
\hline Metric for Thermal Factor & Minimum & Median & Maximum \\
\hline Mean temperature $\left({ }^{\circ} \mathrm{C}\right)^{1}$ & 21.6 & 23.2 & 24.8 \\
Winter & 21.6 & 23.4 & 24.8 \\
Summer & 21.6 & 22.9 & 24.3 \\
Mean relative humidity $(\%)$ & 9.4 & 39.1 & 62.4 \\
Winter & 9.4 & 27.3 & 45.3 \\
Summer & 20.1 & 47.3 & 62.4 \\
Mean humidity ratio & 0.0017 & 0.0069 & 0.0112 \\
Winter & 0.0017 & 0.0050 & 0.0082 \\
Summer & 0.0036 & 0.0083 & 0.0112 \\
Degree-hours above: & & & \\
$20{ }^{\circ} \mathrm{C}\left({ }^{\circ}\right.$-hours) & 14.8 & 29.2 & 43.4 \\
$21{ }^{\circ} \mathrm{C}\left({ }^{\circ}\right.$-hours) & 6.7 & 20.2 & 24.5 \\
$22^{\circ} \mathrm{C}\left({ }^{\circ}\right.$-hours) & 0.94 & 11.28 & 25.7 \\
$23^{\circ} \mathrm{C}\left({ }^{\circ}\right.$-hours) & 0.0 & 4.32 & 17.5 \\
Enthalpy $(\mathrm{kJ} / \mathrm{kg})$ & 26.8 & 41.1 & 52.0 \\
\hline
\end{tabular}

${ }^{1}$ after exclusion of two values at 19.5 and $20.1^{\circ} \mathrm{C}$ 
Table 2. Unadjusted Odds Ratios (ORs) and 95\% Confidence Intervals (CIs) for associations between categorical thermal factors and occupant symptoms in U.S. office buildings in the BASE data, collected 1994-1998.

\begin{tabular}{|c|c|c|c|c|c|c|c|c|c|c|c|c|c|c|c|c|}
\hline \multirow{3}{*}{ Thermal Factor } & \multirow{3}{*}{$\begin{array}{c}\text { Num. } \\
\text { of } \\
\text { Bldgs. }\end{array}$} & \multirow{3}{*}{$\begin{array}{l}\text { Num. of } \\
\text { Subjects }\end{array}$} & \multicolumn{14}{|c|}{ Weekly, Building-Related Symptom Outcomes } \\
\hline & & & \multicolumn{2}{|c|}{$\begin{array}{c}\text { Lower } \\
\text { Respiratory }\end{array}$} & \multicolumn{2}{|c|}{ Cough } & \multicolumn{2}{|c|}{$\begin{array}{c}\text { Upper } \\
\text { Respiratory }\end{array}$} & \multicolumn{2}{|c|}{$\begin{array}{l}\text { Dry or } \\
\text { Irritated } \\
\text { Eyes }\end{array}$} & \multicolumn{2}{|c|}{$\begin{array}{c}\text { Fatigue or } \\
\text { Difficulty } \\
\text { Concentratin } \\
\text { g }\end{array}$} & \multicolumn{2}{|c|}{ Headache } & \multicolumn{2}{|c|}{ Skin } \\
\hline & & & OR & $\begin{array}{c}95 \% \\
\text { CI }\end{array}$ & OR & $\begin{array}{c}95 \% \\
\text { CI }\end{array}$ & OR & $\begin{array}{c}95 \% \\
\text { CI }\end{array}$ & OR & $\begin{array}{c}95 \% \\
\text { CI }\end{array}$ & OR & $\begin{array}{c}95 \% \\
\text { CI }\end{array}$ & OR & $\begin{array}{c}95 \% \\
\text { CI }\end{array}$ & OR & $\begin{array}{c}95 \% \\
\text { CI }\end{array}$ \\
\hline $\begin{array}{l}\text { Mean Temperature: } \\
\text { quartile categories }\end{array}$ & & & & & & & & & & & & & & & & \\
\hline $19.54-22.64$ & 25 & 992 & 1.00 & & 1.00 & & 1.00 & & 1.00 & & 1.00 & & 1.00 & & 1.00 & \\
\hline $22.65-23.21$ & 25 & 1091 & 0.88 & $\begin{array}{l}0.56- \\
1.37 \\
0.84-\end{array}$ & 1.28 & $\begin{array}{l}0.84- \\
1.96 \\
0.87-\end{array}$ & 0.96 & $\begin{array}{l}0.78- \\
1.20 \\
1.02-\end{array}$ & 1.03 & $\begin{array}{l}0.82- \\
1.30 \\
1.00-\end{array}$ & 0.89 & $\begin{array}{l}0.70- \\
1.13 \\
0.92-\end{array}$ & 0.99 & $\begin{array}{l}0.77- \\
1.27 \\
1.09-\end{array}$ & 1.12 & $\begin{array}{l}0.75- \\
1.68 \\
0.59-\end{array}$ \\
\hline $23.24-23.55$ & 21 & 1034 & 1.27 & $\begin{array}{l}1.93 \\
0.59-\end{array}$ & 1.32 & $\begin{array}{l}2.02 \\
0.99\end{array}$ & $1.26^{*}$ & $\begin{array}{l}1.56 \\
0.83-\end{array}$ & 1.25 & $\begin{array}{l}1.57 \\
0.92-\end{array}$ & 1.15 & $\begin{array}{l}1.45 \\
0.74-\end{array}$ & $1.39 *$ & $\begin{array}{l}1.76 \\
0.78-\end{array}$ & 0.91 & $\begin{array}{l}1.39 \\
0.75-\end{array}$ \\
\hline $\begin{array}{l}\quad 23.56-24.83 \\
\text { Degree-Hours Above } \\
23^{\circ} \mathrm{C}: 3 \text { categories }\end{array}$ & 24 & 1049 & 0.92 & 1.43 & 1.49 & 2.26 & 1.04 & 1.29 & 1.16 & 1.46 & 0.94 & 1.19 & 1.00 & 1.28 & 1.13 & 1.70 \\
\hline$<1.5$ & 22 & 836 & 1.00 & & 1.00 & & 1.00 & & 1.00 & & 1.00 & & 1.00 & & 1.00 & \\
\hline $1.5-9.0$ & 62 & 2871 & 1.06 & $\begin{array}{l}0.71- \\
1.57 \\
0.70-\end{array}$ & $1.63^{*}$ & $\begin{array}{l}1.08- \\
2.45 \\
0.97-\end{array}$ & 1.16 & $\begin{array}{l}0.95- \\
1.40 \\
0.94-\end{array}$ & $1.26^{*}$ & $\begin{array}{l}1.02- \\
1.55 \\
1.01-\end{array}$ & 1.03 & $\begin{array}{l}0.84- \\
1.28 \\
0.83-\end{array}$ & 1.07 & $\begin{array}{l}0.86- \\
1.33 \\
0.64-\end{array}$ & 1.00 & $\begin{array}{l}0.69- \\
1.45 \\
0.77-\end{array}$ \\
\hline$>9.0$ & 11 & 459 & 1.22 & 2.12 & 1.68 & 2.92 & 1.24 & 1.65 & $1.37 *$ & 1.84 & 1.12 & 1.53 & 0.90 & 1.26 & 1.28 & 2.14 \\
\hline $\begin{array}{l}\text { Relative Humidity: } \\
\text { quartile categories } \\
\quad<27.69 \%\end{array}$ & 25 & 1104 & 1.00 & & 1.00 & & 1.00 & & 1.00 & & 1.00 & & 1.00 & & 1.00 & \\
\hline$>27.69-39.18 \%$ & 23 & 984 & 1.49 & $\begin{array}{l}0.98- \\
2.29\end{array}$ & 1.30 & $\begin{array}{l}0.89- \\
1.91\end{array}$ & 1.14 & $\begin{array}{l}0.93- \\
1.41\end{array}$ & 1.23 & $\begin{array}{l}0.99- \\
1.54\end{array}$ & 0.95 & $\begin{array}{l}0.75- \\
1.20\end{array}$ & 0.96 & $\begin{array}{l}0.75- \\
1.22\end{array}$ & 1.29 & $\begin{array}{l}0.88- \\
1.90\end{array}$ \\
\hline $\begin{array}{l}>39.18-47.51 \% \\
>47.51 \%\end{array}$ & 24 & 1108 & 1.37 & $\begin{array}{l}0.90- \\
2.09 \\
0.58- \\
1.50\end{array}$ & 1.11 & $\begin{array}{l}0.76- \\
1.63 \\
0.52- \\
1.24\end{array}$ & 0.98 & $\begin{array}{l}0.80- \\
1.20 \\
0.67- \\
1.03\end{array}$ & 1.04 & $\begin{array}{l}0.83- \\
1.29 \\
0.81- \\
1.27\end{array}$ & 1.12 & $\begin{array}{l}0.90- \\
1.39 \\
0.64- \\
1.04\end{array}$ & $\begin{array}{l}1.05 \\
0.89\end{array}$ & $\begin{array}{l}0.83- \\
1.32 \\
0.69- \\
113\end{array}$ & 0.96 & $\begin{array}{l}0.64- \\
1.43 \\
0.53- \\
125\end{array}$ \\
\hline $\begin{array}{l}\text { Humidity Ratio x } 10^{3} \text { : } \\
3 \text { categories }\end{array}$ & & & & & & & & & & & & & & & & \\
\hline $\operatorname{HR} \times 10^{3}<=4$ & 18 & 773 & 1.00 & & 1.00 & & 1.00 & & 1.00 & & 1.00 & & 1.00 & & 1.00 & \\
\hline
\end{tabular}


BASE-Therm_acctd_6-18-09.doc rev 6-18-09

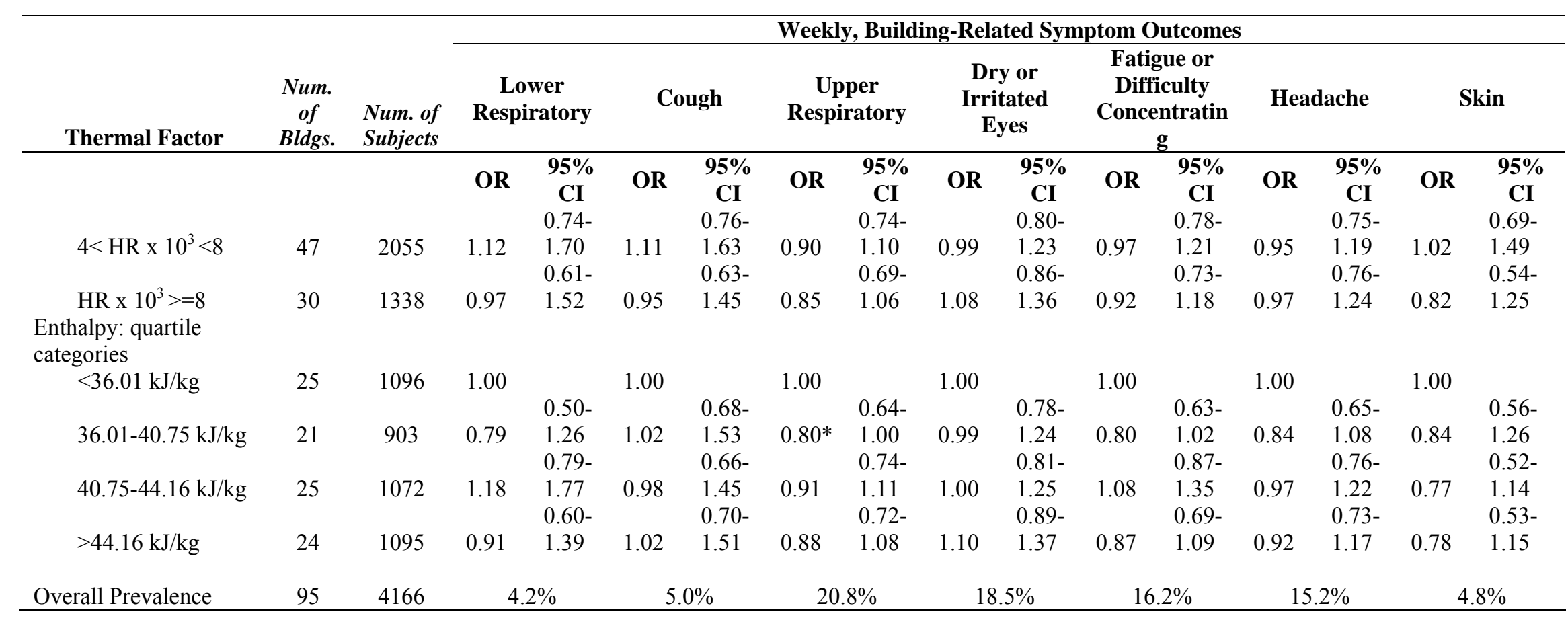


Table 3. Unadjusted odds ratios (ORs) and 95\% confidence intervals (CIs) for associations between unit increases in continuous thermal factor variables and occupant symptoms in U.S. office buildings ${ }^{1}$ in the BASE data, collected 1994-1998.

\begin{tabular}{|c|c|c|c|c|c|c|c|c|c|c|c|c|c|c|}
\hline \multirow[b]{3}{*}{ Thermal Factor } & \multicolumn{14}{|c|}{ Weekly, Building-Related Symptom Outcomes } \\
\hline & \multicolumn{2}{|c|}{$\begin{array}{c}\text { Lower } \\
\text { Respiratory }\end{array}$} & \multicolumn{2}{|c|}{ Cough } & \multicolumn{2}{|c|}{$\begin{array}{c}\text { Upper } \\
\text { Respiratory }\end{array}$} & \multicolumn{2}{|c|}{$\begin{array}{c}\text { Dry or } \\
\text { Irritated Eyes }\end{array}$} & \multicolumn{2}{|c|}{$\begin{array}{c}\text { Fatigue or } \\
\text { Difficulty } \\
\text { Concentrating } \\
\end{array}$} & \multicolumn{2}{|c|}{ Headache } & \multicolumn{2}{|c|}{ Skin } \\
\hline & OR & $\begin{array}{c}95 \% \\
\text { CI }\end{array}$ & OR & $\begin{array}{c}95 \% \\
\text { CI }\end{array}$ & OR & $\begin{array}{c}95 \% \\
\text { CI }\end{array}$ & OR & $\begin{array}{c}95 \% \\
\text { CI }\end{array}$ & OR & $95 \%$ CI & OR & $95 \%$ CI & $\mathbf{O R}$ & $95 \%$ CI \\
\hline $\begin{array}{l}\text { Mean Temperature } \\
\left({ }^{\circ} \mathrm{C}\right)\end{array}$ & 1.05 & $\begin{array}{l}0.83- \\
1.31\end{array}$ & $1.27^{*}$ & $\begin{array}{l}1.03- \\
1.57\end{array}$ & $1.12 *$ & $\begin{array}{l}1.00- \\
1.25\end{array}$ & $1.16^{*}$ & $\begin{array}{l}1.03- \\
1.31\end{array}$ & 1.05 & $\begin{array}{l}0.93- \\
1.19\end{array}$ & 1.07 & $\begin{array}{l}0.94- \\
1.22\end{array}$ & 1.08 & $\begin{array}{l}0.87- \\
1.34\end{array}$ \\
\hline $\begin{array}{c}\text { Degree-Hours Above } \\
20^{\circ} \mathrm{C}(\div 9)\end{array}$ & 1.05 & $\begin{array}{c}0.84- \\
1.32\end{array}$ & $1.26^{*}$ & $\begin{array}{l}1.02- \\
1.56\end{array}$ & $1.12^{*}$ & $\begin{array}{l}1.00- \\
1.26\end{array}$ & $1.17 *$ & $\begin{array}{l}1.03- \\
1.31\end{array}$ & 1.05 & $\begin{array}{l}0.93- \\
1.19\end{array}$ & 1.07 & $\begin{array}{l}0.94- \\
1.22\end{array}$ & 1.09 & $\begin{array}{l}0.87- \\
1.35\end{array}$ \\
\hline $\begin{array}{c}\text { Degree-Hours Above } \\
21^{\circ} \mathrm{C}(\div 9)\end{array}$ & 1.04 & $\begin{array}{c}0.83- \\
1.32\end{array}$ & $1.27^{*}$ & $\begin{array}{l}1.02- \\
1.58\end{array}$ & 1.12 & $\begin{array}{l}1.00- \\
1.26\end{array}$ & $1.16^{*}$ & $\begin{array}{l}1.03- \\
1.31\end{array}$ & 1.05 & $\begin{array}{c}0.93- \\
1.20\end{array}$ & 1.07 & $\begin{array}{l}0.93- \\
1.22\end{array}$ & 1.08 & $\begin{array}{l}0.87- \\
1.35\end{array}$ \\
\hline $\begin{array}{l}\text { Degree-Hours Above } \\
222^{\circ} \mathrm{C}(\div 9)\end{array}$ & 1.03 & $\begin{array}{l}0.79- \\
1.35\end{array}$ & $1.28^{*}$ & $\begin{array}{l}1.00- \\
1.64\end{array}$ & 1.12 & $\begin{array}{l}0.98- \\
1.28\end{array}$ & $1.16^{*}$ & $\begin{array}{l}1.01- \\
1.34\end{array}$ & 1.06 & $\begin{array}{l}0.91- \\
1.22\end{array}$ & 1.04 & $\begin{array}{l}0.90- \\
1.21\end{array}$ & 1.09 & $\begin{array}{c}0.84- \\
1.40\end{array}$ \\
\hline $\begin{array}{l}\text { Degree-Hours Above } \\
223^{\circ} \mathrm{C}(\div 9)\end{array}$ & 1.01 & $\begin{array}{c}0.69- \\
1.48\end{array}$ & 1.20 & $\begin{array}{c}0.85- \\
1.70\end{array}$ & 1.10 & $\begin{array}{c}0.91- \\
1.32\end{array}$ & 1.14 & $\begin{array}{c}0.93- \\
1.39\end{array}$ & 1.08 & $\begin{array}{c}0.88- \\
1.33\end{array}$ & 0.95 & $\begin{array}{l}0.76- \\
1.18\end{array}$ & 1.09 & $\begin{array}{l}0.76- \\
1.57\end{array}$ \\
\hline $\begin{array}{l}\text { Relative Humidity } \\
\quad(\%)(\div 5)\end{array}$ & 1.01 & $\begin{array}{c}0.95- \\
1.07\end{array}$ & 1.00 & $\begin{array}{l}0.95- \\
1.05\end{array}$ & 0.98 & $\begin{array}{l}0.95- \\
1.01\end{array}$ & 1.00 & $\begin{array}{l}0.97- \\
1.03\end{array}$ & 0.99 & $\begin{array}{l}0.96- \\
1.02\end{array}$ & 0.99 & $\begin{array}{l}0.96- \\
1.02\end{array}$ & 0.97 & $\begin{array}{l}0.92- \\
1.02\end{array}$ \\
\hline $\begin{array}{l}\text { Humidity Ratio } \\
\qquad(\text { x } 1,000)\end{array}$ & 1.01 & $\begin{array}{c}0.94- \\
1.08\end{array}$ & 1.00 & $\begin{array}{c}0.94- \\
1.07\end{array}$ & 0.98 & $\begin{array}{c}0.95- \\
1.01\end{array}$ & 1.00 & $\begin{array}{l}0.97- \\
1.04\end{array}$ & 0.99 & $\begin{array}{c}0.96- \\
1.03\end{array}$ & 0.99 & $\begin{array}{l}0.95- \\
1.03\end{array}$ & 0.96 & $\begin{array}{l}0.91- \\
1.03\end{array}$ \\
\hline Enthalpy (kj/kg) & 1.00 & $\begin{array}{c}0.98- \\
1.03\end{array}$ & 1.00 & $\begin{array}{c}0.98- \\
1.03\end{array}$ & 0.99 & $\begin{array}{c}0.98- \\
1.01\end{array}$ & 1.00 & $\begin{array}{c}0.99- \\
1.02\end{array}$ & 1.00 & $\begin{array}{c}0.98- \\
1.01\end{array}$ & 1.00 & $\begin{array}{c}0.98- \\
1.01\end{array}$ & 0.99 & $\begin{array}{c}0.96- \\
1.01\end{array}$ \\
\hline
\end{tabular}

1 These models contained data from 95 buildings and 4,166 occupants.

2 Estimates are per unit increase in each thermal factor within the observed range; e.g., mean temperature, $1^{\circ} \mathrm{C}$; degree-hour variables, 9 degree-hours; relative humidity, $5 \%$; humidity ratio, $1 \times 10^{3}$; enthalpy, $1 \mathrm{kj} / \mathrm{kg}$. 
Table 4. Adjusted Odds Ratios (ORs) and 95\% Confidence Intervals (CIs) from logistic regression models with generalized estimating equations for associations between occupant symptoms and thermal factors in U.S. office buildings in the BASE study, 1994-1998

\begin{tabular}{|c|c|c|c|c|c|c|c|c|c|c|c|c|c|c|}
\hline & \multicolumn{14}{|c|}{ Weekly, Building-Related Symptoms ${ }^{1}$} \\
\hline & \multicolumn{2}{|c|}{$\begin{array}{c}\text { Lower } \\
\text { Respiratory }\end{array}$} & \multicolumn{2}{|c|}{ Cough } & \multicolumn{2}{|c|}{$\begin{array}{c}\text { Upper } \\
\text { Respiratory }\end{array}$} & \multicolumn{2}{|c|}{$\begin{array}{c}\text { Dry or Irritated } \\
\text { Eyes }\end{array}$} & \multicolumn{2}{|c|}{$\begin{array}{c}\text { Fatigue or Difficulty } \\
\text { Concentrating }\end{array}$} & \multicolumn{2}{|c|}{ Headache } & \multicolumn{2}{|c|}{$\begin{array}{l}\text { Irritated or } \\
\text { Itching Skin }\end{array}$} \\
\hline \multicolumn{15}{|l|}{ Model I $^{2}$} \\
\hline \multicolumn{15}{|c|}{ Temperature: quartile categories } \\
\hline $21.60-22.64$ & 1.00 & & 1.00 & & 1.00 & & 1.00 & & 1.00 & & 1.00 & & 1.00 & \\
\hline $22.65-23.21$ & 0.82 & $\begin{array}{c}0.50- \\
1.34\end{array}$ & 1.28 & $\begin{array}{l}0.76- \\
2.14\end{array}$ & 0.98 & $\begin{array}{l}0.78- \\
1.25\end{array}$ & 1.04 & $\begin{array}{c}0.81- \\
1.34\end{array}$ & 0.97 & $0.75-1.26$ & 1.01 & $\begin{array}{c}0.77- \\
1.32\end{array}$ & 0.95 & $\begin{array}{c}0.58 \\
1.56\end{array}$ \\
\hline $23.24-23.55$ & 1.08 & $\begin{array}{l}0.66- \\
1.76\end{array}$ & 1.03 & $\begin{array}{c}0.60- \\
1.78\end{array}$ & 1.03 & $\begin{array}{l}0.81- \\
1.32\end{array}$ & 1.04 & $\begin{array}{l}0.80- \\
1.35\end{array}$ & 1.05 & $0.81-1.38$ & $1.35^{*}$ & $\begin{array}{l}1.04- \\
1.76\end{array}$ & $0.57 *$ & $\begin{array}{l}0.33 \\
0.98\end{array}$ \\
\hline $23.56-24.83$ & 0.78 & $\begin{array}{c}0.47- \\
1.28 \\
\end{array}$ & 1.48 & $\begin{array}{l}0.89- \\
2.44\end{array}$ & 0.95 & $\begin{array}{c}0.75- \\
1.21 \\
\end{array}$ & 1.08 & $\begin{array}{c}0.84- \\
1.40 \\
\end{array}$ & 0.95 & $0.73-1.23$ & 1.03 & $\begin{array}{c}0.79- \\
1.34 \\
\end{array}$ & 1.02 & $\begin{array}{l}0.61- \\
1.70 \\
\end{array}$ \\
\hline \multicolumn{15}{|c|}{ Humidity Ratio: 3 categories } \\
\hline $\begin{array}{l}\mathrm{HR} \times 10^{3} \\
<=4\end{array}$ & 1.00 & & 1.00 & & 1.00 & & 1.00 & & 1.00 & & 1.00 & & 1.00 & \\
\hline $\begin{array}{l}4<\mathrm{HR} \times 10^{3} \\
<8\end{array}$ & 0.97 & $\begin{array}{l}0.59- \\
1.60\end{array}$ & $1.67^{*}$ & $\begin{array}{l}1.03- \\
2.73\end{array}$ & 1.02 & $\begin{array}{l}0.80- \\
1.30\end{array}$ & 1.17 & $\begin{array}{l}0.90- \\
1.51\end{array}$ & 1.12 & $0.86-1.47$ & 1.06 & $\begin{array}{c}0.81- \\
1.39\end{array}$ & 1.03 & $\begin{array}{r}0.63 \\
1.71\end{array}$ \\
\hline $\begin{array}{l}\mathrm{HR} \times 10^{3} \\
>=8\end{array}$ & 0.62 & $\begin{array}{l}0.34- \\
1.15\end{array}$ & 1.40 & $\begin{array}{l}0.74- \\
2.64\end{array}$ & 0.84 & $\begin{array}{l}0.62- \\
1.15\end{array}$ & 1.21 & $\begin{array}{l}0.87- \\
1.68\end{array}$ & 0.91 & $0.65-1.27$ & 1.05 & $\begin{array}{c}0.75- \\
1.49\end{array}$ & 1.01 & $\begin{array}{r}0.52 \\
1.94\end{array}$ \\
\hline \multicolumn{15}{|l|}{ Model $\mathrm{II}^{3,4}$} \\
\hline \multicolumn{15}{|c|}{ Mean Temperature $\left({ }^{\circ} \mathrm{C}\right)$ : continuous } \\
\hline All & 1.00 & $\begin{array}{c}0.79- \\
1.27 \\
\end{array}$ & $1.26^{*}$ & $\begin{array}{l}1.00- \\
1.58 \\
\end{array}$ & 1.05 & $\begin{array}{c}0.93- \\
1.18 \\
\end{array}$ & $1.16^{*}$ & $\begin{array}{l}1.03- \\
1.31 \\
\end{array}$ & 1.04 & $0.91-1.18$ & 1.06 & $\begin{array}{c}0.93- \\
1.21 \\
\end{array}$ & 1.02 & $\begin{array}{l}0.82- \\
1.28 \\
\end{array}$ \\
\hline Winter & 1.17 & $\begin{array}{c}0.81- \\
1.70 \\
\end{array}$ & $1.68 *$ & $\begin{array}{l}1.17- \\
2.40 \\
\end{array}$ & $1.19 *$ & $\begin{array}{l}1.00- \\
1.42 \\
\end{array}$ & $1.41 *$ & $\begin{array}{l}1.16- \\
1.71 \\
\end{array}$ & $1.45^{*}$ & $1.18-1.78$ & $1.27 *$ & $\begin{array}{l}1.03- \\
1.56 \\
\end{array}$ & 1.32 & $\begin{array}{r}0.94- \\
1.86 \\
\end{array}$ \\
\hline Summer & 0.96 & $\begin{array}{c}0.65- \\
1.40 \\
\end{array}$ & 1.11 & $\begin{array}{c}0.77- \\
1.61 \\
\end{array}$ & 1.00 & $\begin{array}{l}0.83- \\
1.22 \\
\end{array}$ & 1.08 & $\begin{array}{c}0.89- \\
1.32 \\
\end{array}$ & $0.80 *$ & $0.65-0.99$ & 0.88 & $\begin{array}{c}0.70- \\
1.09 \\
\end{array}$ & 0.88 & $\begin{array}{r}0.60 \\
1.29 \\
\end{array}$ \\
\hline \multicolumn{15}{|c|}{ Humidity Ratio $\left(\times 10^{3}\right)$ : continuous } \\
\hline All & 0.96 & $\begin{array}{c}0.86- \\
1.07 \\
\end{array}$ & 1.10 & $\begin{array}{c}0.99- \\
1.22 \\
\end{array}$ & 1.01 & $\begin{array}{c}0.95- \\
1.06 \\
\end{array}$ & 1.01 & $\begin{array}{c}0.98- \\
1.05 \\
\end{array}$ & 1.00 & $0.94-1.06$ & 1.00 & $\begin{array}{c}0.94- \\
1.07 \\
\end{array}$ & 0.99 & $\begin{array}{l}0.89 \\
1.10 \\
\end{array}$ \\
\hline Winter & 0.84 & $\begin{array}{l}0.70- \\
1.02\end{array}$ & 0.96 & $\begin{array}{c}0.82- \\
1.13\end{array}$ & 0.92 & $\begin{array}{l}0.84- \\
1.01\end{array}$ & 0.97 & $\begin{array}{c}0.89- \\
1.07\end{array}$ & 0.94 & $0.85-1.04$ & 0.96 & $\begin{array}{c}0.86- \\
1.06\end{array}$ & 0.94 & $\begin{array}{l}0.80 \\
1.11\end{array}$ \\
\hline Summer & 0.94 & $0.79-$ & 1.12 & $0.96-$ & 1.05 & $0.97-$ & 1.05 & $0.96-$ & 0.94 & $0.86-1.03$ & 0.98 & $0.89-$ & 0.96 & 0.82 \\
\hline
\end{tabular}




\begin{tabular}{|c|c|c|c|c|c|c|c|c|c|c|c|c|c|c|}
\hline & \multicolumn{14}{|c|}{ Weekly, Building-Related Symptoms $^{1}$} \\
\hline & \multicolumn{2}{|c|}{$\begin{array}{c}\text { Lower } \\
\text { Respiratory }\end{array}$} & \multicolumn{2}{|c|}{ Cough } & \multicolumn{2}{|c|}{$\begin{array}{c}\text { Upper } \\
\text { Respiratory }\end{array}$} & \multicolumn{2}{|c|}{$\begin{array}{c}\text { Dry or Irritated } \\
\text { Eyes }\end{array}$} & \multicolumn{2}{|c|}{$\begin{array}{c}\text { Fatigue or Difficulty } \\
\text { Concentrating }\end{array}$} & \multicolumn{2}{|c|}{ Headache } & \multicolumn{2}{|c|}{$\begin{array}{l}\text { Irritated or } \\
\text { Itching Skin }\end{array}$} \\
\hline & & 1.10 & & 1.31 & & 1.14 & & 1.15 & & & & 1.08 & & 1.13 \\
\hline \multicolumn{15}{|l|}{ Model III $^{4}$} \\
\hline \multicolumn{15}{|c|}{ Degree-hours $>23^{\circ} \mathrm{C} \div 9:$ continuous } \\
\hline All & 0.94 & $\begin{array}{l}0.63- \\
1.41\end{array}$ & 1.30 & $\begin{array}{l}0.90- \\
1.88 \\
\end{array}$ & 1.01 & $\begin{array}{l}0.82- \\
1.23\end{array}$ & 1.17 & $\begin{array}{l}0.95- \\
1.44\end{array}$ & 1.04 & $0.84-1.30$ & 0.94 & $\begin{array}{l}0.75- \\
1.19\end{array}$ & 1.06 & $\begin{array}{l}0.72- \\
1.54\end{array}$ \\
\hline Winter & 1.42 & $\begin{array}{l}0.80- \\
2.50\end{array}$ & 1.56 & $\begin{array}{l}0.93- \\
2.60 \\
\end{array}$ & $1.33^{*}$ & $\begin{array}{l}1.01- \\
1.75\end{array}$ & $1.72 *$ & $\begin{array}{l}1.28- \\
2.31\end{array}$ & $1.81^{*}$ & $1.33-2.46$ & 1.19 & $\begin{array}{l}0.86- \\
1.63\end{array}$ & $1.77^{*}$ & $\begin{array}{l}1.06- \\
2.96\end{array}$ \\
\hline Summer & 0.67 & $\begin{array}{l}0.33- \\
1.35\end{array}$ & 1.13 & $\begin{array}{l}0.60- \\
2.14\end{array}$ & 0.77 & $\begin{array}{l}0.55- \\
1.08\end{array}$ & 0.83 & $\begin{array}{l}0.58- \\
1.18\end{array}$ & $0.59^{*}$ & $0.40-0.87$ & $0.66^{*}$ & $\begin{array}{l}0.44- \\
0.97\end{array}$ & 0.58 & $\begin{array}{l}0.29- \\
1.19\end{array}$ \\
\hline \multicolumn{15}{|c|}{ Humidity Ratio $\left(\right.$ x $\left.10^{3}\right)$ : continuous } \\
\hline All & 0.98 & $\begin{array}{l}0.91- \\
1.06 \\
\end{array}$ & 1.03 & $\begin{array}{l}0.96- \\
1.10\end{array}$ & 0.98 & $\begin{array}{l}0.95- \\
1.02\end{array}$ & 1.01 & $\begin{array}{l}0.97- \\
1.04\end{array}$ & 1.00 & $0.96-1.04$ & 0.99 & $\begin{array}{l}0.95- \\
1.03\end{array}$ & 0.97 & $\begin{array}{l}0.90- \\
1.04\end{array}$ \\
\hline Winter & 0.86 & $\begin{array}{l}0.71- \\
1.03\end{array}$ & 0.98 & $\begin{array}{l}0.84- \\
1.15\end{array}$ & 0.93 & $\begin{array}{l}0.86- \\
1.02\end{array}$ & 1.00 & $\begin{array}{l}0.91- \\
1.09\end{array}$ & 0.96 & $0.87-1.06$ & 0.97 & $\begin{array}{l}0.88- \\
1.08\end{array}$ & 0.96 & $\begin{array}{l}0.81- \\
1.13\end{array}$ \\
\hline Summer & 0.92 & $\begin{array}{l}0.78- \\
1.09\end{array}$ & 1.12 & $\begin{array}{l}0.95- \\
1.32\end{array}$ & 1.04 & $\begin{array}{l}0.96- \\
1.13\end{array}$ & 1.04 & $\begin{array}{l}0.95- \\
1.13\end{array}$ & 0.94 & $0.85-1.02$ & 0.97 & $\begin{array}{l}0.88- \\
1.07\end{array}$ & 0.95 & $\begin{array}{l}0.81- \\
1.12\end{array}$ \\
\hline
\end{tabular}

${ }^{1}$ All models unless otherwise noted adjusted for gender, smoking, asthma diagnosis, heating degree days and cooling degree days. Models not stratified by season are also adjusted for season.

${ }^{2}$ Additional adjustments to Model Group I:

Lower respiratory: comfort of desk, comfort of chair, workstation location, building age, years worked in building, mold allergy

Cough: comfort of desk, workstation location, dust allergy, ventilation rate, building age, years worked in building

Upper respiratory: comfort of desk, workstation location, building age, years worked in building

Eyes: comfort of desk, building age, years worked in building

Fatigue/difficulty concentrating: workstation location, building age, years worked in building

Skin: floor area per operable window, comfort of desk, ventilation rate, building age, years worked in building

${ }^{3}$ Model II for Eye only adjusted for gender, smoking, heating degree days and cooling degree days. Models not stratified by season are also adjusted for season.

${ }^{4}$ ORs for continuous thermal factors are estimates per unit increase in each thermal factor within the observed range; e.g., mean temperature, $1{ }^{\circ} \mathrm{C}$; degree-

hours $>23^{\circ} \mathrm{C}, 9$ degree-hours; relative humidity, $5 \%$; humidity ratio, $1 \times 10^{3}$. 


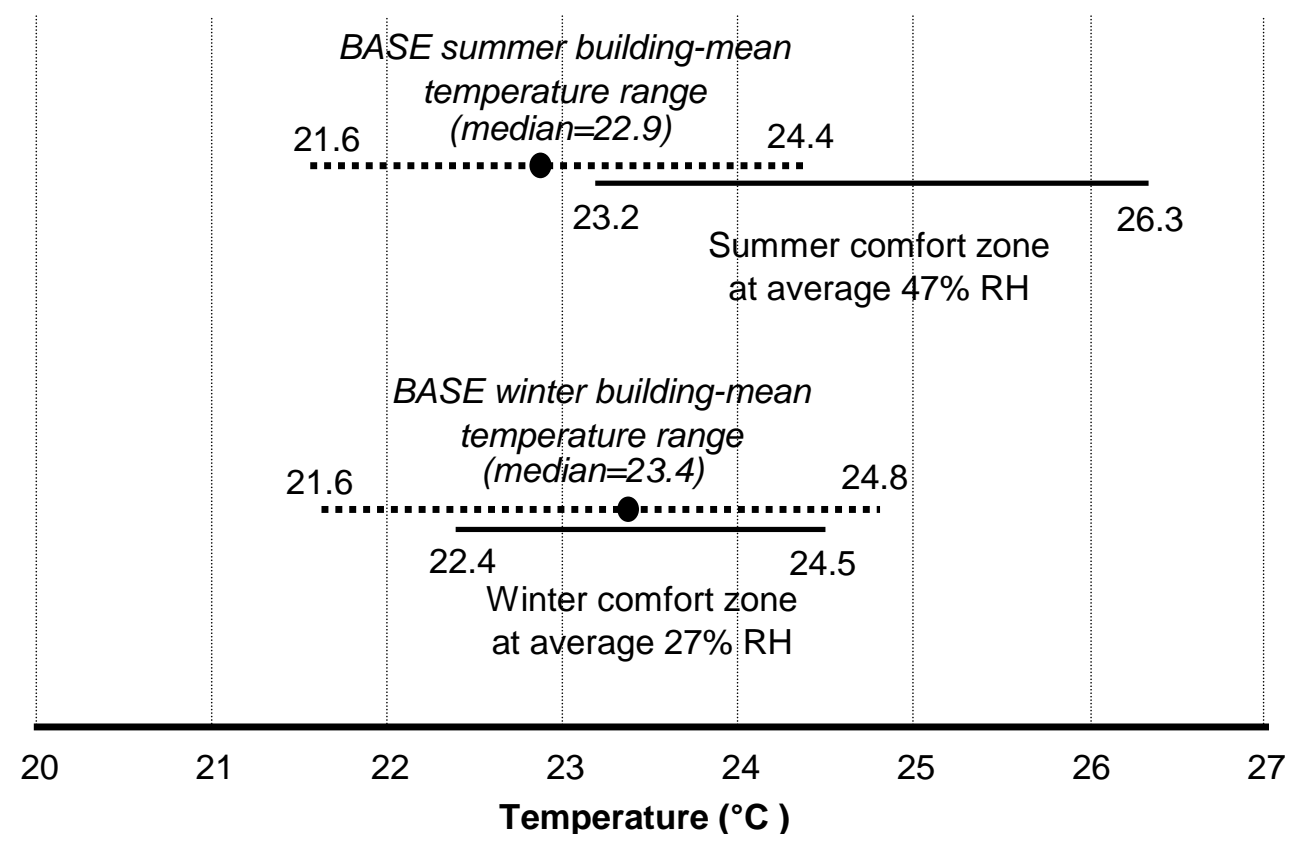

Figure 1. Observed indoor temperatures in BASE buildings relative to recommended thermal comfort guidelines (ASHRAE, 2005b), by season 
BASE-Therm_acctd_6-18-09.doc rev date
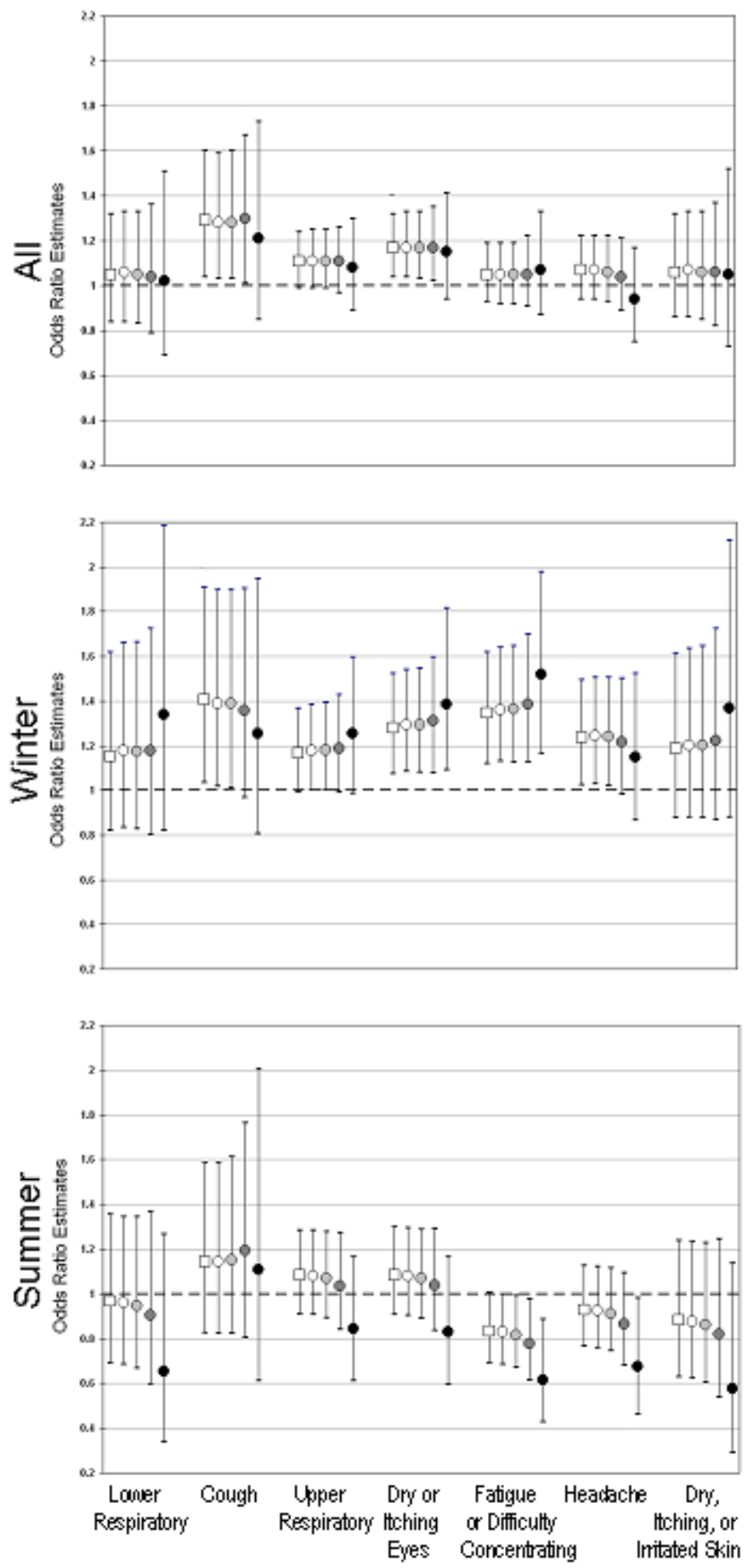

Weekly, Work-Related Symptoms

\begin{tabular}{|ll|}
\hline Legend: & $\square$ Mean Temperature \\
Degree-Hours Above $20^{\circ} \mathrm{C}$ & Degree-Hours Above $22^{\circ} \mathrm{C}$ \\
Degree-Hours Above $21^{\circ} \mathrm{C}$ & Degree-Hours Above $23^{\circ} \mathrm{C}$
\end{tabular}


Figure 2. Estimated odds ratios and $95 \%$ confidence limits for the associations between weekly work-related symptoms and five continuous metrics of temperature, adjusted for humidity ratio 